\title{
THE RISE AND GROWTH OF SERBIAN BANKING UNTIL WORLD WAR I** Part Two: The Second Stage - The National State and the National Banking (1878-1914)
}

The development of Serbian banking during the $19^{\text {th }}$ century was a gradual process that underwent two distinctive stages with the turning point in 1878 when Serbia became an independent state by the international agreement concluded at the Berlin Congress. In the first stage, until 1878, necessary political, economic and institutional preconditions had been formed for the rise of banking that led to the creation of the first organized credits and banks. During the second stage, decisive programme of economic and institutional development and modernization resulted in the mushrooming growth of banks. Apart from The Privileged National Bank of the Kingdom of Serbia (National Bank), as a bank of note issue, there were state banks and privately-owned banks mostly in the form of joint-stock companies. From 1894, farmers started to establish farm cooperative societies as institutions that met their credit needs with a much more favourable terms than banks. Analyses suggests that banks in the Kingdom of Serbia during 1878-1914 period better served the development of trade, building of the infrastructure (railroads) and industry than credit needs of the farmers who were the main economic agent of the country representing 85\% of the total population.

Keywords: credit institutions, banks, National Bank, credit demand, interest rates, paid-up capital, usury, foreign banks.

* Professor Biljana Stojanović, PhD

Faculty of Geoeconomics, John Naisbitt University, Belgrade, Serbia bstojanovic@naisbitt.edu.rs

* This paper was prepared and presented in English language on XV World Economic History Congress, held in Utrecht, the Netherlands, from 3 to 7 August, 2009. 


\section{Introduction - Modernization and Development (1878-1914)}

Political independence gained at the Berlin Congress in 1878, set in motion process of state and economic development and modernization of Serbia along the lines of Western-European countries. During this period main pillars of modern European state were created - democratic constitution (1888) and legislation, multiparty political system, the central bank, regular army, the first railroads, stock exchange, obligatory primary education and Serbian Academy of Sciences and Arts, to mention just a few of them.As for the economic development, decision about the national economic strategy was among the first decisions that forged this process of a economic modernization and development.

After vehement internal debates between liberals and protectionists over the national economic strategy, Prince Milan Obrenović and his government adopted export-led economic strategy with a liberal foreign trade policy. This decision was contrary to the decisions made by the majority of the newly independent states that usually adopted import-substitution strategy with high level of protection in order to initiate or stimulate development of the national industry. ${ }^{1}$ Although at that time the world entered second stage of industrialization, Serbia did not close itself to begin national industry. Instead, Serbia started its national economic growth with already existing resources and economic branches - agriculture and foreign trade.

Based on this national economic strategy, foreign trade grew almost threefold between 1879 and 1911- from 80,6 million dinars in 1879 to 232,3 million dinars in 1911 (Table 1, Appendix).But, what was more important than this steady rise in the volume of trade was its balance - from 1888 there was permanent trade surplus until 1912. That year deficit occurred as a consequence of the preparations for the Balkan Wars (1912-13).

Serbia's main foreign partner was Austria from which Serbia imported industrial and to which exported agricultural products - mainly cattle. Comparing to Austria, and some other neighbouring countries, Serbia was far ahead in livestock breeding (Table1). Simultaneously with great advance in livestock breeding, there was also growth of arable land that led to a significant rise in crop farming - especially in wheat and maizeproduction. Between 1867 and 1910, maize production rose more than fourfold and wheat more than threefold. ${ }^{2}$

About circumstances and reasons that led Prince Milan to adopt export-led economic strategy see: Stojanović, B. (1992): Iz ekonomsko-finansijske i političke istorije Srbije (18781918), Finansije, broj 3-4, Beograd.

2 Dva veka razvoja Srbije - Statistički pregled, (Two Centuries of Serbian Development Statistical Review), (oktobar 2008): Republički zavod za statistiku, Beograd, p. 121. 
Table 1. Livestock in Austria and some Balkan Countries (1900) (per thousand inhabitants)

\begin{tabular}{|c|c|c|c|c|}
\hline Country & Cattle & Pigs & Sheep & Horses \\
\hline Austria & 387 & 123 & 173 & 66 \\
\hline Hungary & 335 & 288 & 629 & 132 \\
\hline Romania & 366 & 165 & 690 & 85 \\
\hline Serbia & 623 & 988 & 2516 & - \\
\hline
\end{tabular}

Source: Berend, I. (1974), p. 57.

Until 1906, Austria absorbed on average 86\% of the Serbian exports and supplied about $65 \%$ of its imports. ${ }^{3}$ Liberal imports of industrial goods from Austria prevented the ascent of Serbian industry. Thus, adopted export-led economic strategy made a certain paradox - politically independent Serbia became economically dependent on Austria and for that Prince Milan was severely criticized. But permanent surpluses in foreign trade and big advance in agriculture justified the chosen economic strategy. Good results in these two sectors paved the way for the overall economic growth and opened opportunities for the later development of the industry. The minimum conditions necessary for the industrialization started to appear at the end of 1880s and were reinforced after the Custom War with Austria (1906- 1911). ${ }^{4}$ The Idustrialization policy, governed by the Ministy for the National Economy, gave priority to those industries that could be supplied by domestic resources. ${ }^{5}$ Thus, industrialuization began with food processing, textiles and mining. A Total number of industrial enterprises rose from 156 in 1893 to 464 in 1910 (Table 2).

Table 2. Industrial development in Serbia 1893-1910

\begin{tabular}{|c|c|c|c|c|c|c|c|c|c|c|c|c|c|c|}
\hline Year & $\stackrel{\text { ฒ}}{\circ}$ & $\begin{array}{l}\stackrel{2}{\circ} \\
\stackrel{0}{\sigma}\end{array}$ & $\begin{array}{l}\text { ळે } \\
\text { (2) }\end{array}$ & ஜ & ळ & §ั & ஜ̊ & ఫั & ڤ̊ & ஜ̊ & 응 & $\stackrel{\circ}{\circ}$ & $\frac{0}{2}$ & $\bar{\sigma}$ \\
\hline $\begin{array}{c}\text { Number } \\
\text { enterprises }\end{array}$ & 156 & 243 & 256 & 268 & 282 & 292 & 350 & 360 & 383 & 375 & 416 & 448 & 464 & - \\
\hline $\begin{array}{c}\text { Real } \\
\text { growth } \\
\text { rates in \%* }\end{array}$ & - & 23,8 & 7,7 & 28,6 & 8,3 & 5,1 & 1,0 & $-4,7$ & 7,5 & 16.3 & 22,0 & 13,1 & 2,9 & 47,9 \\
\hline
\end{tabular}

${ }^{*}$ of industrial production (prices 1898)

Source: Stojanović, B. (1992), p. 172.

Stojanović, B. (1992): p.173.

Đunisijević, R. (1990): Osnivanje industrijskih preduzeća i razvoj industrije u Srbiji do 1918. godine, BIGZ, Beograd, p. 9.

Ibid. 277. 
Custom war finally put an end to predominant position of Austria in Serbian foreign trade since Serbia succeededin opening new foreign markets for its exports by concluding trade agreements with Germany, Russia, Italy, France and England.

After 1878, Serbian population rose from about two million in 1884 to nearly three million in 1911 (Table 2 Appendix). Therapid demographic upsurge increased potential workforce and widened inner market making strong impetus for overall economic growth. At the same time, however, the share of town population did not increase markedly, in comparison to the period until 1878. In 1910 , town population accounted for only $13 \%$, and Belgrade population $3 \%$ of the total population (Figure1). This was demographic reflection of the economic structure despite decisive step forward in economic transformation from 1878, Serbia remained agricultural country till World War I.

Figure 1. Share of Towns and Belgrade in Total Population 1884-1910.

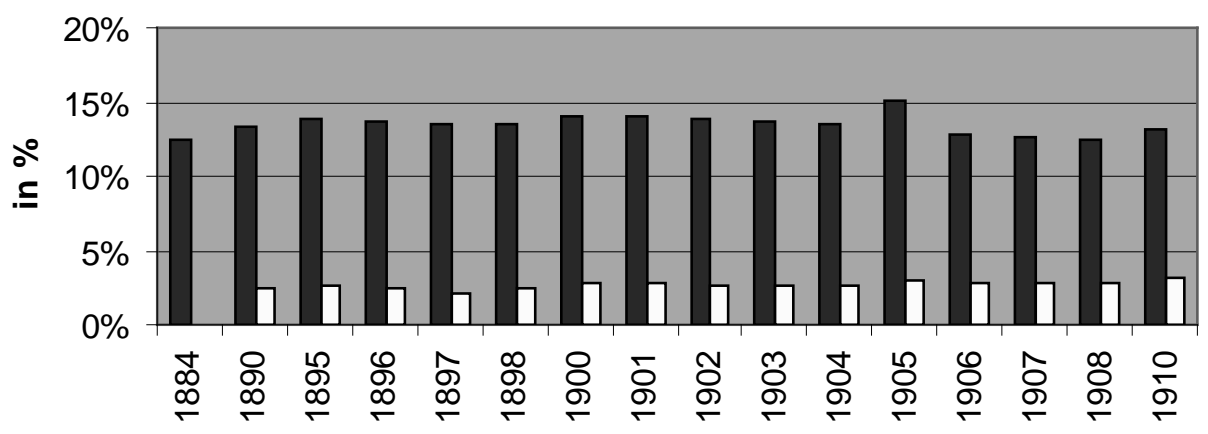

Share of Towns $\square$ Share of Belgrade

Source: Table 2 in Appendix

\section{The Structure of Credit Institutions in the Kingdom of Serbia}

The first Serbian economic strategy of export-led growth and liberal trade, resulted in expansion of domestic and foreign trade that increased the volume of monetary and credit transactions. This was conducive to the creation of banks and a host of various types of credit institutions were set up by 1914. Also, monetary sovereignty, with the dinar as a national currency, finally facilitated realization of a long-existing idea of the creation of the National Bank in 1884.

Monetary legislation of 1868, 1873, and 1878, introduced bimetallism, i.e. limping gold standard, as a monetary system of the Kingdom of Serbia. ${ }^{6}$ The

$6 \quad$ See: Gnjatović, D. (2006): The Introduction of Limping Gold Standard in the Principality of Serbia, in: Avramov, R. And Pamuk, S. eds., Monetary and Fiscal Policies in South-East 
legislation envisaged the minting of gold coins of 20 and 10 dinars, silver coins of 5,2,1 and 0,5 dinars as well as copper small coins of 10, 5, 2 and 1 paras. ${ }^{7}$ The sole right to mint coins was in the hands of the Serbian State. The first gold coins of 20 dinars (calledMilandors) were put into circulation in 1879 in the amount of 10 million dinars and first silver coins in 1880 in the amount of 3,6 million dinars. ${ }^{8}$ Adopted bimetallism was the basis that later allowed National Bank to issue notes convertible in both - gold and silver. Parallel circulation of gold and silver notes lasted util 1914.

The structure of credit organization of the Kingdom of Serbia until 1914 was comprised of the following institutions:

1) Privileged National Bank of the Kingdom of Serbia (National Bank)

2) State credit institutions:

- Administration of Funds

- State Savings Houses (former District Savings Houses)

3) Privately-owned credit institutions in the form of:

- joint-stock companies (with various names: savings houses, banks, credit houses, savings cooperatives)

- private banks and exchange offices

- mixed partnerships (limited liability)

4) Farm Cooperative Societies

Until the 1914, all these domestic credit institutions underwent certain transformations and foreign banks appeared following the increasing credit demands of the economy.

\section{Privileged National Bank of the Kingdom of Serbia (National Bank)}

The National Bank was set up as privately-owned joint stock company with the main purpose to provide cheap credits in order to help development of trade and production in the Kingdom of Serbia. ${ }^{9}$ The main instrument for achieving this purpose was the issuance of notes that would increase the supply of money and flexibility of the monetary system.

It was interesting that even before political independenceand the creation of the National Bank, The Act on the Issuance of Paper Money had been adopted in

Europe, Comparative and Historical Perspective, Bulgarian National Bank, Sofia.

Srpske novine, 19.12.1878.

Dugalić, V. (1999): Narodna banka 1884-2004, Jugoslovenski pregled, Beograd, p22.

Zakon o Narodnoj banci, 6. Januar 1883. god.

Vol. 14, № 1, 2017: 1-26 
1876. In compliance with this act, Serbian State printed the notes of 100, 50, 10, 5 and 1 dinar but they were not put into circulation. ${ }^{10}$

By the adoption of TheAct on the National Bankin 1883, National Bank was created under the name of ThePrivileged National Bank of the Kingdom of Serbia. This act established monopoly of note issue for the National bank - no other bank in Serbia was allowed to issue notes. Also, the act prescribed that the notes were fully and unconditionally convertible into gold (Article 10) and that a minimum metal cover was $40 \%$ for the notes in circulation (Article 11). ${ }^{11}$ The convertible notes of the National Bank were proclaimed acceptable by the state cash desk (Article 12), which meant that they became legal tender. ${ }^{12}$ The first notes of 100 dinars were put into circulation on July 15,1884 by way of discounting credits with $5,5 \%$ interest and lombard credits with 6,5\% interest. ${ }^{13}$ However, due to the problem of maintaining gold notes in circulation, National Bank startedin 1885with issuing notes backed by silver (silver notes)which gradually became dominant in circulation - just before the First World War their share in circulation was $95 \%{ }^{14}$

The authorized capital of the National Bank was 20 million dinars the payment of which was divided into two subscription series of 10 million dinars each. The payment of the first subscription was being carried out throughout almost three decades and was ended in 1912. The national Bank started its operation in 1884 with subscribed capital of 2,5 million dinars.

Throughout the period, the minimum legal cover of $40 \%$ was strictly observed as well as convertibility of the gold and silver notes. Redemption of notes was suspended only on two occasions - at the outbreak of the Balkan War (1912) and on the eve of World War I.

Apart from issuing notes, the National Bank applied other instruments for providing cheap credits. One of the major instruments was its discount policy by which discount rates was set in the range of $4,5-8 \%$ per annum throughout the period until $1914 .^{15}$

The National Bank was allowed to advance credits to the State, banks and private firms. These credits took the form of discount operations, lombard credits and current account operations (collateralized loans).

With its operations, the National Bank primarily met demand of merchants, craftsmen and industrialist for short-term credits. ${ }^{16}$ However, national plans

$10 \quad$ About these notes see: Hadži-Pešić, J. (1995): Novac Srbije 1868-1918, Zavod za izdavanje novčanica, Beograd., p. 62.

11 Zakon o Narodnoj banci, 6. Januar 1883 god.

12 Ibid.

13 Dugalić, V. (1994): Konvertibilnost dinara u periodu 1884-1941, Finansije 5-6, Beograd, p. 256.

$14 \quad$ Ibid. 258.

15 Dugalić, V. (1999), p. 244.

16 Glomazić, M. (1933): Istorija Državne Hipotekarne Banke 1862-1932, Narodna misao, Beograd, p 68. 
and endeavors for economic development and modernization required strong credit institutions able to provide long-term loans. To achievethis aim, the State reformed already existing state credit institutions - District Savings Houses and the Administration of Funds.

\section{State credit institutions}

The name of the former District Savings Houses was changed in State Savings Houses. To the existing five houses, State added another two by establishing one in Niš (1881) and second in Vranje (1886). However, all these savings houses began to show losses from 1888 due to poor organization, prolongation of maturities, non-performing loans and weak control of their work. In 1894, the Decree on liquidation of the State Savings Houses was passed, according to which all their assets and liabilities were transferred to the Administration of Funds. ${ }^{17}$ Official statistics recorded separately the data on State Savings Houses even beyond 1894 because their liquidation was slow and long process that lasted almost until World War I. Financial resources and debtors of the seven State Savings Houses are presented in Table 3.

Table 3. State Savings Houses in Serbia 1888-1899

\begin{tabular}{|c|c|c|c|}
\hline Year & $\begin{array}{c}\text { Number of Savings } \\
\text { Houses }\end{array}$ & $\begin{array}{c}\text { Creditors' Capital } \\
\text { In mill. dinars }\end{array}$ & Number of Debtors \\
\hline 1888 & 7 & 4,40 & 9695 \\
\hline 1889 & 7 & 4,40 & 6663 \\
\hline 1890 & 7 & 3,63 & 6835 \\
\hline 1891 & 7 & 3,63 & 6168 \\
\hline 1892 & 7 & 3,58 & 4744 \\
\hline 1893 & 7 & 3,64 & 6156 \\
\hline 1894 & 7 & 3,64 & 5845 \\
\hline 1895 & 7 & 4,20 & 6800 \\
\hline 1896 & 7 & 4,10 & 6762 \\
\hline 1897 & 7 & 4,00 & 6451 \\
\hline 1898 & 7 & 3,10 & 4822 \\
\hline 1899 & 7 & 4,80 & 5784 \\
\hline
\end{tabular}

Source: Statistički godišnjak Kraljevine Srbije, various years.

In 1898, Administration of Funds was reformed. The new legislation did not change the principal aim and financial sources of the Administration of Funds. As before, it was allowed to advance long-term loans at an interest rate of $6 \%$ per

Arhiv Srbije, Zbornik zakona (1894): Zbornik 50, p. 1.

Vol. 14, № 1, 2017: 1-26 
annum secured by immovable property and communal loans secured, either by immovable property or, by the revenues of the local authorities. Financial sources were also the same - public and court funds, private deposits, bonds and mortage debentures (that could be sold on domestic and foreign markets). Securities issued by the Administration of Funds were given the status of the government securities. The significance of the new legislation was in the fact that it enabled transformation of the Administration of Funds from the simple state financial department into a proper state mortgage bank that began with strict application of banking principles, disciplines and procedures.

Until World War I, the Administration of Funds remained the biggest national mortgage bank. Its financial sources amounted to 68 million dinars in 1908 and 65 million dinars in $1909 .{ }^{18}$ In the respective years, total paid-up capital of all privately-owned Serbian banks was much lower - about 40 million dinars (Table 4).

In 1913, the structure and amounts of financial sources of the Administration of Funds were as follows: ${ }^{19}$

1. public and court funds

2. private deposits

3. foreign debentures

4. domestic debentures
53 million dinars

5 million dinars

60 million dinars

1,5 million dinars

Total amount

119,5 million dinars

As it is seen, foreign debentures were the largest source of capital for the Administration of Funds. This verified how important was the role of the Administration of Funds in raising capital for the national economy on the foreign financial market. In this regard, the work of the Administration of Funds was in complete contrast to the operations of the First Serbian Bank from the previous period (1869-75) which better served foreign than the national interests. This favourable change was certainly the result of the great improvements in banking skills of the Serbian government and other private bankers.

\footnotetext{
18 Glomazić, M. (1933), p. 92.

19 Kukla, S. (1924): Razvitak kreditne organizacije u Srbiji, Komisionalna naklada Hrvatski štamparski zavod, Zagreb, p. 31.
} 


\section{Privately-owned Credit Institutions}

Before the creation of the National Bank, several new banks had appeared - Šabac Savings House (1880), Belgrade Cooperative (1882), Serbian Credit Bank (1882) and Obrenovac Savings House (1884). ${ }^{20}$ In total, only seven banks existed before the creation of the National Bank. ${ }^{21}$ Except for the Serbian Credit Bank, all other banks were of a small size.

The Serbian Credit Bank was the first foreign bank in the Kingdom of Serbia. Its founders were Comptoird'Escompte from Paris and Landerbank from Vienna. ${ }^{22}$ The dominant owner became Landerbank with around $75 \%$ share in paid-up capital that was 1,2 million dinars. With this capital, the Serbian Credit Bank was the leading bank in Serbia until the beginning of the $20^{\text {th }}$ century. Besides, this bank was the first Serbian bank that opened the inland office. This office was set up in Šabac, export center near the Austro-Hungarian border.

After the establishment of the National Bank in 1884, the pace of growth of the privately-owned banks accelerated. The number of these banks rose from 37 in 1888 to 187 in 1912 (Table 4). Their total paid-up-capital increased from 8,6 to 60,3 million dinars in the respective years. Data presented in Table 4 include all privately-owned banks in Serbia - domestic and foreign alike.

Privately-owned credit institutions appeared under different names - banks, credit houses, savings houses and savings cooperatives. The newspapers, literature and official statistics at the time, used the word "money house" as a general term for all these institutions. ${ }^{23}$ Here arose questions - how these differences in names actually occurred and whether these different names reflected differences in the nature of these credit institutions?

Owing to the shortage of money and capital in Serbia, the first domestic credit institutions were set up in the form of savings cooperatives for mutual help of their members. Customarily, payments for the subscribed capital of the savings cooperatives was divided into several installments. Shares were of small denominations - 50 or 100 dinars. However, even the payment of one installment was carried out gradually, i.e. not in one sum. Usually, one installment would be paid weekly, i.e. by paying 1 or 0,5 dinars per week. Thus, payment of one installment could last even 100 weeks.

\footnotetext{
20 Dugalić, V. (1999), p.24.

$21 \quad$ Ibid., p. 24 and 90.

22 Mitrović, A. (1999): Foreign Banks in Serbia 1881-2-1914, in: Kostis, K.P. (ed.) Modern Banking in the Balkans and West-European Capital in the $19^{\text {th }}$ Century, Aldershot, p. 76-97.

23 The Serbian term “novčani zavod“ is here translated as „money house“ because early banks are very often called „houses“ in literature. See: Davies, G. (2002): A History of Money From Ancient Times to the Present Day, University of Wales Press, Cardiff, p. 291.
}

Vol. 14, № 1, 2017: 1-26 
Table 4. Banks in the Kingdom of Serbia 1884-1912* in mill. dinars

\begin{tabular}{|c|c|c|c|c|c|c|}
\hline Year & Number & $\begin{array}{c}\text { Paid-up capital } \\
\text { with NB }\end{array}$ & $\begin{array}{c}\text { Paid-up capital } \\
\text { of the NB }\end{array}$ & Profit & $\begin{array}{c}\text { Rate of } \\
\text { return \% }\end{array}$ & $\begin{array}{c}\text { Savings } \\
\text { deposits }\end{array}$ \\
\hline 1884 & 7 & 5,7 & 2,5 & & & \\
\hline 1885 & - & - & 2,5 & & & \\
\hline 1886 & & & 2,5 & & & \\
\hline 1887 & & & 2,5 & & & \\
\hline 1888 & 37 & 8,6 & 2,5 & 0,926 & 11 & \\
\hline 1889 & 40 & 9,8 & 2,5 & 0,923 & 9 & \\
\hline 1890 & 42 & 10,6 & 2,5 & 1,18 & 11 & \\
\hline 1891 & 45 & 11,6 & 2,5 & 1,28 & 11 & \\
\hline 1892 & 67 & 12,0 & 2,5 & 1,56 & 13 & \\
\hline 1893 & 61 & 13,5 & 2,5 & 1,64 & 12 & \\
\hline 1894 & 62 & 14,5 & 2,5 & 1,62 & 11 & \\
\hline 1895 & 66 & 15,1 & 2,5 & 1,90 & 13 & \\
\hline 1896 & 69 & 17,9 & 3,7 & 1,83 & 20 & \\
\hline 1897 & 69 & 18,9 & 4,9 & 1,88 & 10 & \\
\hline 1898 & 76 & 20,5 & 4,9 & 2,30 & 11 & \\
\hline 1899 & 76 & 20,8 & 4,9 & 2,39 & 11 & \\
\hline 1900 & 81 & 21,6 & 4,9 & 2,38 & 11 & 20,8 \\
\hline 1901 & 92 & 23,2 & 4,9 & 2,64 & 11 & 21,8 \\
\hline 1902 & 105 & 24,8 & 4,9 & 2,76 & 11 & 21,4 \\
\hline 1903 & - & - & 4,9 & - & - & 23,9 \\
\hline 1904 & 111 & 27,8 & 4,9 & 3,33 & 12 & 27,8 \\
\hline 1905 & 114 & 29,5 & 5,0 & 2,42 & 8 & 31,0 \\
\hline 1906 & 118 & 29,0 & 5,0 & - & - & 35,2 \\
\hline 1907 & 129 & 32,9 & 5,0 & 3,76 & 11 & 39,5 \\
\hline 1908 & 146 & 39,7 & 7,5 & 4,07 & 10 & 35,0 \\
\hline 1909 & 150 & 41,0 & 7,5 & & & - \\
\hline 1910 & 163 & 53,2 & 7,5 & & & 54,5 \\
\hline 1911 & 175 & 53,3 & 7,5 & & 8 & 65,0 \\
\hline 1912 & 187 & 60,3 & 9,1 & & 9 & 65,0 \\
\hline
\end{tabular}

* Without the Administration of Funds and seven State Savings Houses

Source: 1. For 1888-1908 period: Statistički godišnjak Kraljevine Srbije, various years.

2. For 1909-1912 period: Author's calculation on the basis of Kukla (1924) andMitrović (1999) 
Figure 2. Banks in the Kingdom of Serbia 1884-1912.

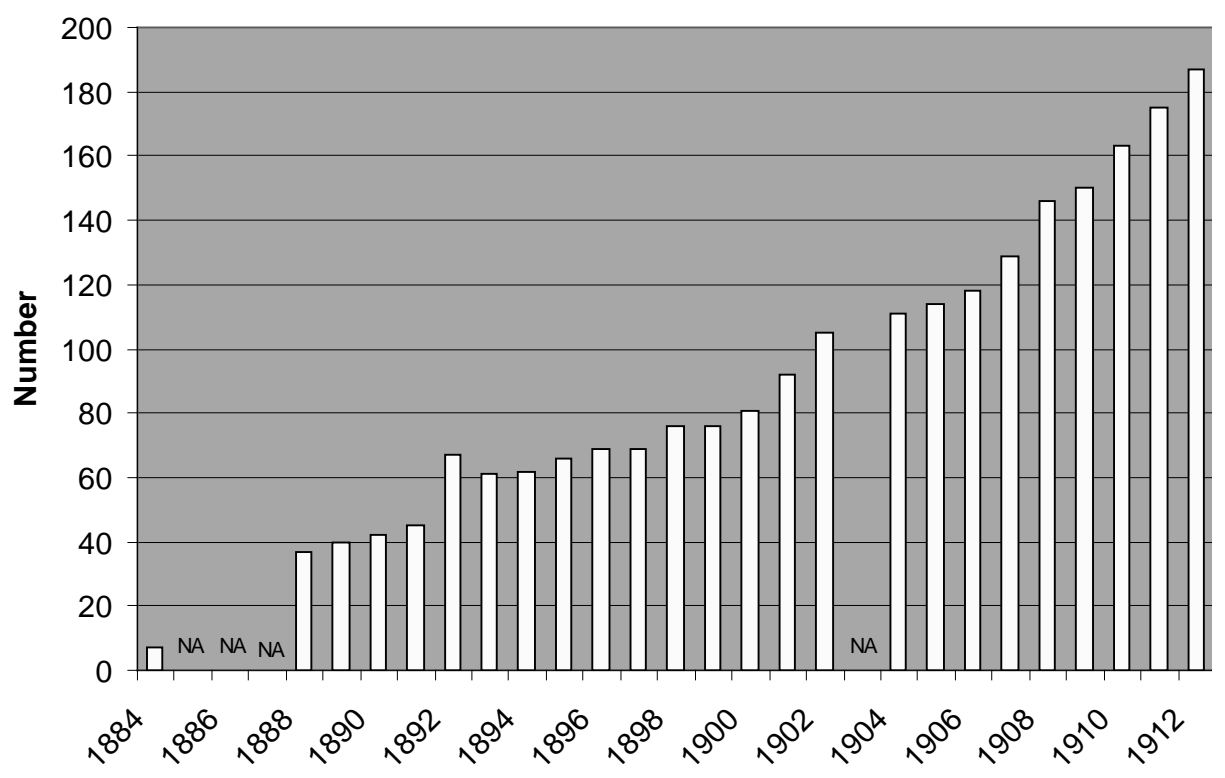

Source: Table 4

Figure 3. Paid-up Capital of Banks 1884-1912.

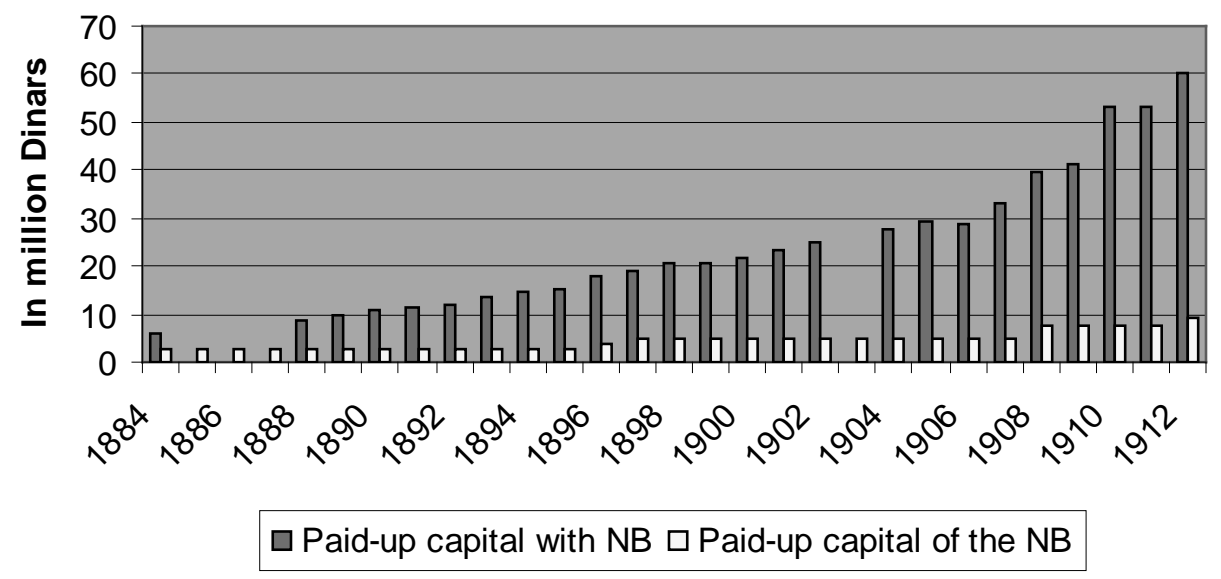

Source: Table 4

Upon the payment of subscribed capital, majority of these savings cooperatives began to advance credits beyond their membership, i.e. to non-members and thus transformed themselves into real banks taking the organizational form of partner- 
ships of the mixed or joint-stock form as was defined by the provisions of The Commercial Law (Chapter III). When The Act on Joint Stock Companies was adopted in 1896, majority of these bank partnerships assumed the form of real joint-stock companies. But during all these transformations they retained their original names. Thus, differences in the names actually reflected the organizational evolution of credit institutions more than differences in the nature of their businesses. This was also officially recognized. From 1906, official statistics of the Kingdom of Serbia discontinued with classifying "money houses" into four categories - banks, credit houses, savings houses and savings cooperatives arguing that all these institutions actually were of the same nature. ${ }^{24}$ But, official statistics continued to use the term "money houses" for credit institutions instead of the term "bank", perhaps because there wasn't any legislature on banks that would define them.

As the essence of the banking business is giving credits and taking deposits, this paper would continue to use the term "banks" for Serbian credit institutions since they all were doing this essential banking business. However, Serbian banks also developed various other banking and, even, not strictly banking operations that would be presented later.

\section{Foreign Banks in the Kingdom of Serbia}

Foreign banks established operations in Serbia during 1880s as creditors of the Serbian State. They were advancing loans for the construction of the first Serbian railways for which domestic credit institutions did not have enough resources. Some of the foreign banks came to Serbia opening their branches and daughter banks (Table 5). These foreign banks were not numerous but in terms of paid-up capital were very important.

It is already mentioned that Serbian Credit Bank, set up in 1882, was the first foreign bank in Serbia. Later, another seven foreign banks were founded as daughter banks or branches of the foreign banks. Bank Andrejević and Co was set up in 1882 as a domestic bank but became foreign in 1888 when it was taken over by the Hungarian commercial Bank of Pest. In 1910 the bank was reorganized as a joint-stock company with $60 \%$ stake of the mentioned Hungarian bank and $40 \%$ stake of a new co-owner German bank Berliner Handelsgesellschaft. The branch of the Prague Credit Bank was founded in summer 1910 and only a few weeks later the French-Serbian Bank was created with head office in Paris and the branch office in Belgrade. The founders of the French-Serbian Bank were strong French banks that represented powerful concern of international proportions. This bank had a predominant position in the Serbian banking before World War I. The Danubian Joint Stock Trade Company was the creation of the Budapest branch of the Serbian Bank from Zagreb (Hungary). In early autumn

$24 \quad$ Statistički godišnjak Kraljevine Srbije, 1907, 1908. Prefice. 
1912, Serbian authorities granted a license for the creation of Serbian-English Bank but this bank never started to work perhaps due to three successive wars in 1912, 1913 and 1914. On the eve of World War I, bank Fatherland was established with Hungarian capital and Imobilijarna banka with French capital but they did not start to work..$^{25}$

Table 5. Foreign Banks in the Kingdom of Serbia 1878-1914

\begin{tabular}{|c|c|c|c|c|}
\hline Name & $\begin{array}{c}\text { Year of } \\
\text { establishment }\end{array}$ & Country of origine & $\begin{array}{c}\text { Paid-up or } \\
\text { Authorized capital* }\end{array}$ & Branches \\
\hline Serbian Credit Bank & 1882 Daughter-bank & Austria/France & 1,2 & 1 (Šabac) \\
\hline Bank Andrejević \& Co. & $\begin{array}{c}\text { 1882/1888** } \\
\text { Daughter-bank }\end{array}$ & Hungary/Germany & 1,0 & 1 (Niš) \\
\hline Prague Credit Bank & $\begin{array}{c}1910 \\
\text { Branch }\end{array}$ & Czech Republic & $5,0^{* * *}$ & - \\
\hline French-Serbian Bank & $\begin{array}{c}1910 \\
\text { Branch }\end{array}$ & France & 4,0 & $\begin{array}{l}2 \text { (Skoplje } \\
\text { and Bitolj) }\end{array}$ \\
\hline $\begin{array}{l}\text { Danubian Joint Stock } \\
\text { Trade Company }\end{array}$ & $\begin{array}{c}1911 \\
\text { Daughter-bank }\end{array}$ & $\begin{array}{l}\text { Serbian Bank from } \\
\text { Zagreb (Hungary) }\end{array}$ & 0,6 & - \\
\hline Serbian-English Bank ${ }^{* * *}$ & 1912 & England & $5,0 * * * *$ & - \\
\hline $\begin{array}{l}\text { Imobilijarna } \\
\text { banka }\end{array}$ & 1914 & France & $1,0^{* * * *}$ & \\
\hline Fatherland & 1914 & Hungary & - & - \\
\hline
\end{tabular}

*In million dinars

** Bank was established in 1882 but became foreign in 1888 .

${ }^{* * *}$ It was not discernable from the sources if this was authorized or paid-up capital

${ }^{* * * * \text { Authorized capital }}$

Source: Kukla (1924), Mitrović (1999) and Milić (1992).

In addition to purely banking operations, foreign banks, especially Prague Credit Bank and French-Serbian Bank, engaged themselves in Serbian industry. The Prague Credit Bank, among other industrial undertakings, set up and run sugar plant, modern textile plant and chemical plant. For the industrial and communal projects, the French-Serbian Bank founded separate company the "French-Serbian Society for Industrial Firms and Public Works".

Except for the foreign banks and the Administration of Funds, the majority of domestic Serbian banks did not open branches. However, branches of the Administration of Funds were not much of a help in mobilizing savings from inland Serbia or providing credits in the provinces because they had right solely to collect

25 Milić, D. (1992): Učešće Jevreja u bankarstvu Srbije do Prvog svetskog rata, Jevrejski istorijski muzej, Zbornik 6, p. 181 and Kukla (1924), p. 32. 
repayments of its loans. Merely the head office in Belgrade could approve loans to borrowers. The National Bank also did not have branches. Only after the Balkan Wars (1912), when Serbia got new territories on the south, it opened branches in Skoplje and Bitolj. Just three Belgrade banks followed suit. Since having branches was rarely the case, Serbian banking had a character of a unit banking.

\section{Factors of the Mushrooming Growth of Banks}

There were many factors contributing to the fast growth of the number of banks from 1884 - political, economic and institutional and they were intricately interwoven. Surely, the major factor was political independence that stands as a milestone for other factors since it forged independent national economic system and policy. Another crucial factor was chosen national economic strategy of export-led growth with liberal trade because it resulted in vibrant trade and increased demand for money and credit. Creation of the dinar as a national currency and the National Bank were the leading institutional monetary factors that contributed to the growth of banks.

Apart from mentioned primary factors, there were also other important factors. One of those was the incompleteness of the The Act on Joint-stock Companies (1896). This act missed to define minimum capital requirement and also allowed companies to start working only with the payment of $10 \%$ of the subscribed capital. But, there was no any authorized body or mechanism for controlling if this $10 \%$ were really paid-up in money terms or not. All these deficiencies in legislation on joint-stock companies contributed to easy and fast creation of banks.

Political parties took advantage of these legal circumstances giving additional impetus to the rise of the number of banks. They began to create their own banks as a method of political competition. By offering high deposit rates in their banks, political parties tried to win elections. To this end, political parties used to open banks even in villages. One example is the small village of Azanjathat had three banks. ${ }^{26}$

Unit character of bankingwas another factor of fast creation of banks since the lack of branches was compensated by the opening of the new banks, especially in the provinces.

Analyzing the functioning of the credit market, the National Bank concluded that competition of too many small banks actually led to high market interest rates which annihilated its efforts of providing cheap credits to the economy. The government also realized this problem. At first, it decided to liquidate certain small banks but later it took the initiative to remove deficiencies in legislation, especially regarding the minimum capital requirements, in order to prevent further creation of very small banks.

26 Avramović, M. (1914): Zemljoradnik i novčani zavod, Pijemont, Beograd, p. 18. 


\section{The Importance of the Serbian Banks for the Economy}

The level of interest rate could be considered as the main indicator of the importance of banks for the economy. This stems from the very purpose of the banks' existence - to supply the economy with money at the lowest costs possible. Apart from the interest rates, there are other indicators that could show the significance of the banks for the economy. This analysis uses some quantitative and qualitative indicators: the level of the interest rates, several ratios that show the size of the banking sector and geographical distribution of banks in the Kingdom of Serbia.

\subsection{Lending Rates of the Banks}

Monetary history shows that some countries applied severe measures for those who jeopardize monetary stability or practice usury. In this regard, England is such an egregious example. Even in the $19^{\text {th }}$ century, people in England were hanged for counterfeiting and forgery. ${ }^{27}$ Usurious practices were thwarted from the early $12^{\text {th }}$ century by the official setting of the maximum interest rates and punishment of expulsion from the country. In 1242, the king James I, fixed the interest by law at $18 \%$ but in practice it was disregarded. ${ }^{28}$ The Jews, who arrived in England about the time of the Conquest, immediately became remarkable for usury why they were expelled from England in 1290 and were not readmitted until $1656 .{ }^{29}$ In 1546 , the taking of interest for money was made legal in England, and the rate of interest was fixed at $10 \%$. In time, the legal rate was reduced in 1624 to $8 \%$, in 1651 to $6 \%$, in 1714 to $5 \%$ where it stood during the 1830 s. $^{30}$

In the $19^{\text {th }}$ century Serbia, the widespread usury had also been tried to be discouraged by the letter of the law. The Civil Code, adopted in 1844, prescribed that the lawful interest was $6 \%$ and maximum interest $12 \% .{ }^{31}$ It also forbade the practice of compound interest. ${ }^{32}$

Until the creation of the National Bank in 1884, interest rates of $11 \%$ and $12 \%$ were common in Belgrade while that of $10 \%$ was considered as low but in interior Serbia the rates were much higher. After 1884, however, market rates decreased throughout the country - in Belgrade to 6-8\% and in provences to $11-12 \% .^{33}$

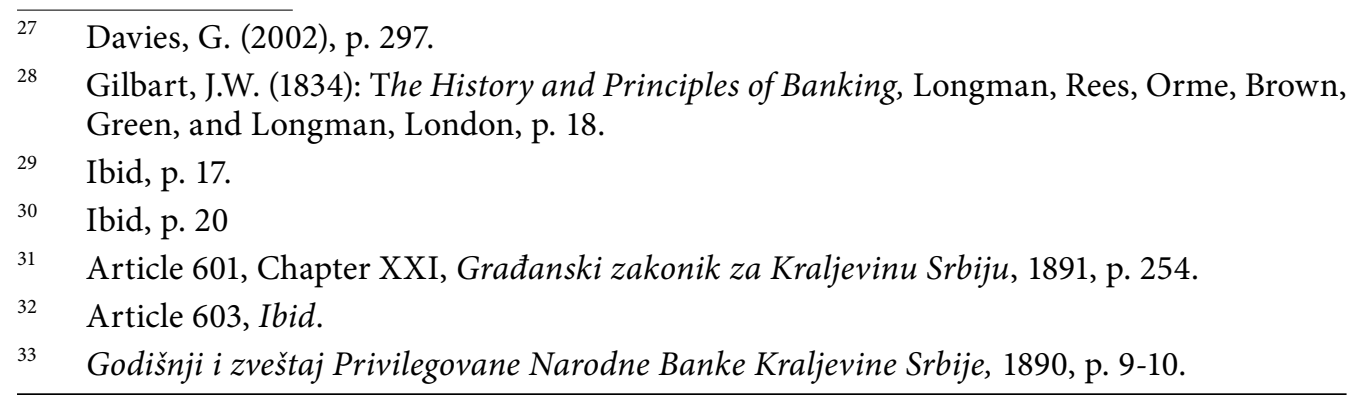

Vol. 14, № 1, 2017: 1-26 
Table 6. Annual Lending Rates of the Serbian Banks 1888-1908 in \%

\begin{tabular}{|c|c|c|c|}
\hline Year & Number of Banks & Minimum Lending Rate & Maximum Landing Rate \\
\hline 1888 & 37 & 6,5 & 12 \\
\hline 1889 & 40 & 8 & 12 \\
\hline 1890 & 43 & $41 / 3$ & 12 \\
\hline 1891 & 45 & 5,5 & 11 \\
\hline 1892 & 67 & 6 & 12 \\
\hline 1893 & 61 & 5 & 12 \\
\hline 1894 & 62 & 4 & 12 \\
\hline 1895 & 66 & 5 & 12 \\
\hline 1896 & 69 & 5 & 12 \\
\hline 1897 & 69 & 4 & 12 \\
\hline 1898 & 76 & 4 & 12 \\
\hline 1899 & 76 & 4 & 12 \\
\hline 1900 & 81 & 3 & 12 \\
\hline 1901 & 92 & 5 & 12 \\
\hline 1902 & 105 & 4 & 12 \\
\hline 1903 & - & - & - \\
\hline 1904 & 111 & 6 & 12 \\
\hline 1905 & 114 & 6 & 12 \\
\hline 1906 & 118 & - & - \\
\hline 1907 & 129 & 8 & 12 \\
\hline 1908 & 146 & $71 / 2$ & 12 \\
\hline & & & \\
\hline
\end{tabular}

Source: Statistički godišnjak Kraljevine Srbije, various years.

According to the official statistics, the annual lending rate of the Serbian banks varied from the minimum of 3\% to maximum of $12 \%$ between 1888 and 1908. (Table 6). The minimum rate emerged only once - in 1900 but the maximum rate of $12 \%$ was constantly present.

The lowest lending rates were charged by large Belgrade banks but the majority of provincial banks charged the maximum legal rate of $12 \%$. Unofficial sources from the literature claimed that provincial banks actually charged the interest of $20-30 \% .{ }^{34}$ After the Balkan Wars, in the new south territories, according to unofficial sources, lending rates reached even $40-50 \%$ and often $100 \% .^{35}$

What could be the proof of these claims? The first proof could be the official data on the banks' profits shown in Table 4 . These figures show that banks' rates of returns were very high - averaging 11,1\% during 1888-1912 period.

Kukla, S. (1924), p. 57.

Ibid. 
A spontaneous creation of farm cooperative societies could be considered as the second proof of the high and usurious lending rates of the banks. Dissatisfied with the credit terms of the banks, farmers started to organize their own credit institution from 1894 when the first farm cooperative society was established. In three years there were 35 and in 1913 about 700 of such societies. Some sources report the existence of about 1000 farm cooperative societies in $1914 .^{36}$

Discussions in the National Assembly about usury was also evidence of the problem. In 1913, for example, banks were accused of ruining farmers in Smederevo district. ${ }^{37}$ Some representatives even raised the question of "bankocracy" - the rule of banks in Serbia.

At the same time, some authors in literature resolutely claimed that "bank credits were not suitable for agriculture at all" and that "capitalistic institutions (money houses) could not solve the problem of usury." 38

\subsection{Other Indicators of the Banks' Importance}

There are two most commonly used quantitative indicators of the banks' importance for the economy. The first measures the size of the banking sector relative to the national income or GDP of a country and the second measures the size of banking sector relative to population.

Geographical distribution of banks is a qualitative indicator showing the level of concentration of banking services, i.e. level of the access of city and provincial dwellers to the bank funds.

In order to reckon these indicators, reliable data are needed. In case of the Kingdom of Serbia, some indicators could not be reckon due to non-existence of data, lack of reliable data or broken time series. This problem was tried to be overcome by acceptable adjustments of the indicators or time series where possible.

The first indicator was impossible to calculate because there was no data on Serbian national income and GDP for the period until World War I. As a surrogate for the missing national income and GDP, total foreign trade is taken for calculation because firstly, foreign trade was one of the most important economic activity in Serbia throughout the $19^{\text {th }}$ century and, as such, total foreign trade could be taken as an indicator of the trend of the overall economic activity; secondly, there were official data on foreign trade for the whole period.

As mentioned earlier, there was steady increase of the volume of Serbian foreign trade until 1912 indicating steady economic growth (Table 1 Appendix). At the same time, the ratio of banks' paid-up capital to total foreign trade was also increasing - from the level of $6,3 \%$ in 1884 to $31,7 \%$ in 1912 , suggesting that importance of the banking sector for the economy was growing. (Figure 4 ).

\footnotetext{
$36 \quad$ Avramović, M. (1914), p. 51.

$37 \quad$ Ibid. p.25.

$38 \quad$ Ibid. p. 29 and 90.
}

Vol. 14, № 1, 2017: 1-26 
Figure 4. Share of Banks Paid-up capital in Foreign Trade.

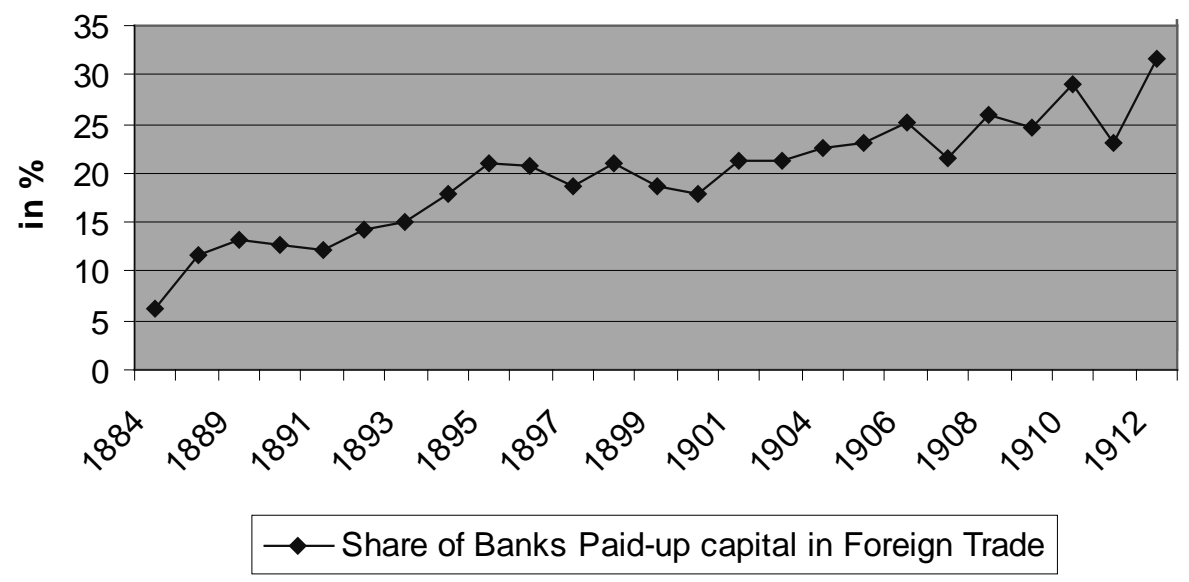

Source: Table 4 and Table 1 in Appendix

The second indicator - the ratio of population to banks, markedly declined from 271676 inhabitants in 1884 to 16838 in 1911 with the highest decline between 1884 and 1889 (Figure 5). Constant decline in this indicator ment that the access of borrowers to bank services was constantly increasing. This strongly supports the above conclusion of the growing importance of banking sector for the economy between 1884 and 1912 .

Figure 5. Number of Inhabitants per Bank.

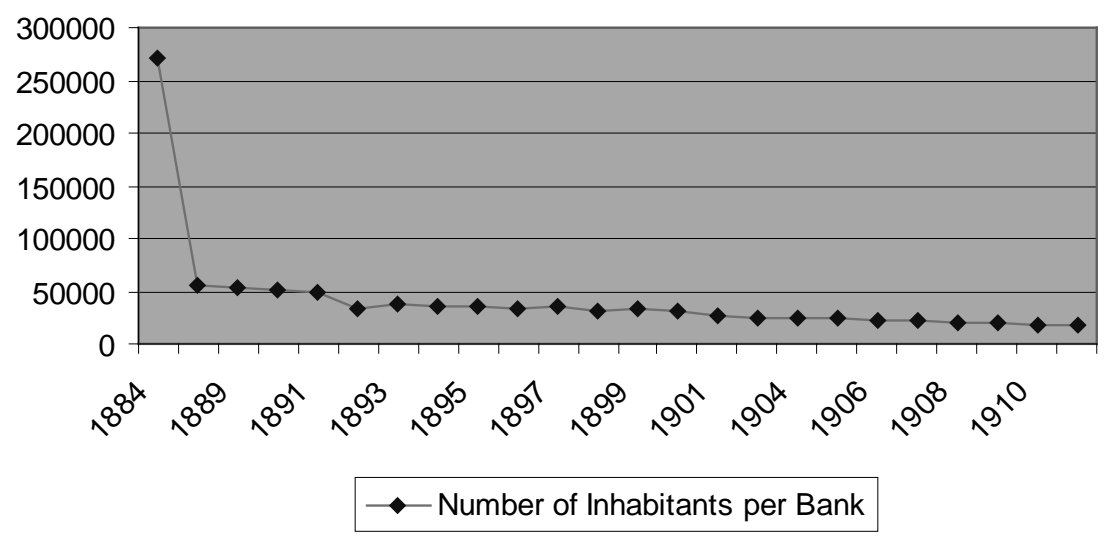

Source: Table 3 in Appendix

When data on geographical distribution of banks are added to the above favourable indicators, than the more realistic picture of the Serbian banking 
appears. Data from Table 7, show that, on the one side, banking sector was concentrated in the capital of Belgrade and on the other, banks in provinces were of a much smaller size than those in Belgrade. The average paid-up capital of banks in Belgrade was about 0,60 million dinars, while that of provincial banks was only about 0,16 million dinars - roughly 3,7 times less. Interestingly enough, these differences in the size are not pronounced in the profits they earned.

Table 7. Banks in Belgrade and Provinces in 1911 and 1912*

\begin{tabular}{|c|cc|cc|cc|cc|}
\hline \multirow{2}{*}{ Year } & \multicolumn{2}{|c|}{ Number of banks } & \multicolumn{2}{|c|}{ Paid-up Capital } & \multicolumn{2}{|c|}{ Average capital } & \multicolumn{3}{|c|}{ Profit } \\
& B & P & B & P & B & P & B & P \\
\hline 1911 & 40 & 134 & 23,4 & 21,8 & 0,58 & 0,16 & 1,7 & 1,9 \\
\hline 1912 & 44 & 143 & 29,3 & 21,9 & 0,66 & 0,15 & 3,1 & 1,7 \\
\hline
\end{tabular}

* $\mathrm{B}=$ Belgrade $\mathrm{P}=$ Provinces

Source: Kukla (1924), p. 60.

Banks with paid-up capital over one million dinars were considered big. ${ }^{39}$ These twelve banks are shown in Table 8. They all had their head office in Belgrade and only foreign banks opened branches in the provinces.

Table 8. The Biggest Serbian Banks in 1913

in mill.dinars

\begin{tabular}{|c|c|c|}
\hline Bank & Year of establishment & Paid-up capital \\
\hline Prague Credit Bank & 1910 & $5,0^{*}$ \\
\hline French-Serbian Bank & 1910 & 4,0 \\
\hline Belgrade Cooperative & 1882 & 2,5 \\
\hline King-Serbian Privileged Export Bank & 1901 & 2,5 \\
\hline Belgrade Trade Bank & 1894 & 2,5 \\
\hline Turnover Bank & 1895 & 1,5 \\
\hline Vračar Cooperative & 1893 & 1,2 \\
\hline Serbian Credit Bank & 1882 & 1,2 \\
\hline Bank Andrejević \& Co. & $1882 / 1888$ & 1,0 \\
\hline Country Bank & 1906 & 1,0 \\
\hline General Economic Bank & 1907 & 1,0 \\
\hline Vračar Savings House & 1898 & 1,0 \\
\hline
\end{tabular}

*It is not certain in the sources if this was authorized or paid-up capital

Source: Kukla (1924) and Table 5.

In the group of the "big five", with capital over two million dinars, the first two banks were foreign banks - Prague Credit Bank and French-Serbian Bank. These

39 Stanarević, Nik. (1912): Beogradske banke u 1911, Štamparija Sv. Sava, Beograd, p. 7. 
banks came to Serbia after the Customs War with Austria when economic activity all over Serbia was flourishing giving to foreign banks bright opportunities, not only for banking, but also for direct industrial activities. Foreign banks were able to meet rising demand for credits with the help of their powerful head offices. Only in 1914, one domestic bank - the King-Serbian Privileged Bank, was able to raise paidup capital to five million dinars, approaching the largest foreign banks in Serbia. ${ }^{40}$

\section{Conclusion}

Decisive programme of economic and institutional development and modernization of the Kingdom of Serbia that began after gaining political independence in 1878, resulted in the mushrooming growth of various types of credit institutions. Apart from the Privileged National Bank of the Kingdom of Serbia (National bank), as a bank of note issue, there were state credit and privatelyowned institutions. The later were mostly in the form of joint-stock companies and operated under the various names - banks, savings societies, credit houses. The majority of private banks were small, unit banks of the universal type but their growth was remarkable - from 7 in 1884 to 187 in 1912. Foreign banks were much larger but not numerous - in 1912 there were five foreign banks in the form of branches and daughters of some European banks. In terms of capital, however, during the whole period the biggest bank was the Administration of Funds which was the state mortgage bank.

Creation of the National bank and other banks contributed to the decline of the lending rates at the banks, but market interest rates remained high and soared to usurious levels (100\%). Surely, lack of capital was the main reason for usury but there were some other factors too - difficiences in legislation, unit character of banking, lack of controlling body for the banks, geographical distribution of banks - to mention few of the basic factors. Private banks were concentrated in the capital of Belgrade which contributed to the violation of the legal maximum rate of $12 \%$, especially by provincial banks. Farmers were especially beset by usury. To save themselves from usury and improve position on the credit market, farmers started from 1894 to create farm cooperative societies as institutions that met their credit needs better than banks. The growth of farm cooperative societies was also remarkable - in 1897 there were 35 and in 1913 about 700 such institutions. In terms of the absolute numbers, farm cooperative societies were more than three times numerous than banks. Analyses suggests that banks in the Kingdom of Serbia during 1878-1914 period better served the development of trade, building of the infrastructure (railroads) and industry than credit needs of the farmers who were the main economic agent of the country representing $85 \%$ of the total population.

$40 \quad$ Kukla, S. (1924), p. 69. 


\section{Literature}

- Arhiv Srbije, (1894): Zbornik zakona, Zbornik 50.

- Avramović, M. (1914): Zemljoradnik i novčai zavod, Pijemont, Beograd.

- Berend, I. (1974): Economic development in East-Central Europe in the $19^{\text {th }}$ and $20^{\text {th }}$ centuries, Columbia University Press, United States of America.

- Davies, G. (2002): A History of Money From Ancient Times to the Present Day, University of Wales Press, Cardiff.

- Dva veka razvoja Srbije - Statistički pregled, (Two Centuries of Serbian Development - Statistical Review), (oktobar 2008): Republički zavod za statistiku, Beograd.

- Dugalić, V. (1994): Konvertibilnost dinara u periodu 1884-1941, Finansije 5-6, Beograd.

- Dugalić, Veroljub (1999): Narodna banka 1884-1941, Jugoslovenski pregled, Beograd.

- Đunisijević, R.(1990): Osnivanje industrijskih preduzeća i razvoj industrije u Srbiji do 1918. godine, BIGZ, Beograd.

- Gilbart, J. W. (1834): The History and Principles of Banking, Longman, Rees, Orme, Brown, Green, and Longman, London.

- Glomazić, M. (1933): Istorija Državne Hipotekarne Banke 1862-1932, Narodna misao, Beograd.

- Gnjatović, D. (2006): The Introduction of Limping Gold Standard in the Principality of Serbia, in: Avramov, R. And Pamuk, S. eds., Monetary and Fiscal Policies in South-East Europe, Comparative and Historical Perspective, Bulgarian National Bank, Sofia.

- Godišnji izveštaj Privilegovane Narodne Banke Kraljevine Srbije, (1890).

- Građanski zakonik za Kraljevinu Srbiju, (1891), u Beogradu, štampa i izdanje Kraljsrpske drž. Štamparije.

- Hadži-Pešić, J. (1995): Novac Srbije 1868-1918, Zavod za izdavanje novčanica, Beograd.

- Kukla, S.(1924): Razvitak kreditne organizacije u Srbiji, Komisionalna naklada Hrvatski štamparski zavod, Zagreb.

- Milić, D. (1992): Učešće Jevreja u bankarstvu Srbije do Prvog svetskog rata, Jevrejski istorijski muzej, Zbornik 6.

- Mitrović, A. (1999): Foreign Banks in Serbia 1881-2-1914, in: Kostis, K.P. (ed.) Modern Banking in the Balkans and West-European Capital in the $19^{\text {th }}$ Century, Aldershot.

- Srpske novine, 19.12.1878.

- Stanarević, Nik. (1912): Beogradske banke u 1911, Štamparija Sv. Sava, Beograd.

- Statistika spoljne trgovine Kraljevine Srbije za 1912, Državna štamparija Kraljevine Srbije 1911. i 1914.

- Statistički godišnjak Kraljevine Srbije, various years.

- Stojanović, B. (1992): Iz ekonomsko-finansijske i političke istorije Srbije (1878-1918), Finansije, broj 3-4, Beograd.

- Zakon o Narodnoj banci, 6. Januar 1883. god. 


\section{APPENDIX}

Table 1. Foreign Trade of the Kingdom of Serbia 1879-1912 in mill. dinars

\begin{tabular}{|c|c|c|c|c|c|c|}
\hline Year & Import & Export & Total & Balance & $\begin{array}{l}\text { Growth of total } \\
\text { trade in \%* }\end{array}$ & $\begin{array}{l}\text { Export growth } \\
\text { in } \%^{*}\end{array}$ \\
\hline 1879 & 41,7 & 38,9 & 80,6 & $-2,8$ & & \\
\hline 1880 & 46,1 & 35,2 & 81,3 & $-10,9$ & 0,8 & -10 \\
\hline 1881 & 43,2 & 40,1 & 83,3 & $-3,1$ & 2,5 & 14 \\
\hline 1882 & 48,5 & 40,3 & 88,8 & $-8,2$ & 6,6 & 0 \\
\hline 1883 & 49,7 & 40,2 & 89,9 & $-9,5$ & 1,2 & 0 \\
\hline 1884 & 50,9 & 39,9 & 90,9 & $-11,0$ & 1,1 & -1 \\
\hline 1885 & 40,5 & 37,6 & 78,1 & $-2,9$ & $-14,0$ & $-6,0$ \\
\hline 1886 & 51,7 & 40,7 & 92,4 & $-11,0$ & 18,3 & 8,0 \\
\hline 1887 & 36,5 & 36,1 & 72,6 & $-0,4$ & $-21,4$ & $-11,0$ \\
\hline 1888 & 35,2 & 38,9 & 74,1 & $+3,7$ & 2,0 & 8,0 \\
\hline 1889 & 34,8 & 39,0 & 73,8 & $+4,2$ & $-0,4$ & 0 \\
\hline 1890 & 38,0 & 45,8 & 83,8 & $+7,8$ & 13,5 & 17,0 \\
\hline 1891 & 42,8 & 52,3 & 95,1 & $+9,5$ & 13,5 & 14,0 \\
\hline 1892 & 37,0 & 46,4 & 83,4 & $+9,4$ & $-12,3$ & $-11,0$ \\
\hline 1893 & 40,9 & 48,9 & 89,8 & $+8,0$ & 7,6 & 5,0 \\
\hline 1894 & 34,8 & 46,0 & 80,8 & $+11,2$ & $-10,0$ & $-6,0$ \\
\hline 1895 & 28,2 & 43,4 & 71,6 & $+15,2$ & $-11,4$ & $-6,0$ \\
\hline 1896 & 33,4 & 53,4 & 86,8 & $+20,0$ & 21,2 & 23,0 \\
\hline 1897 & 45,3 & 55,9 & 101,2 & $+10,6$ & 16,6 & 5,0 \\
\hline 1898 & 41,1 & 56,9 & 98,0 & $+15,8$ & $-3,2$ & 2,0 \\
\hline 1899 & 46,4 & 65,7 & 112,1 & $+19,3$ & 14,4 & 15,0 \\
\hline 1900 & 54,0 & 66,5 & 120,5 & $+12,5$ & 7,5 & 1,0 \\
\hline 1901 & 43,8 & 65,7 & 109,5 & $+21,9$ & $-9,1$ & $-1,0$ \\
\hline 1902 & 44,8 & 72,1 & 116,9 & $+27,3$ & 6,7 & 10,0 \\
\hline 1903 & 58,2 & 59,9 & 118,1 & $+1,7$ & 1,0 & $-17,0$ \\
\hline 1904 & 60,9 & 62,1 & 123,0 & $+1,2$ & 4,1 & 4,0 \\
\hline 1905 & 55,6 & 71,9 & 127,5 & $+16,3$ & 3,6 & 16,0 \\
\hline 1906 & 44,3 & 71,6 & 115,9 & $+27,3$ & 9,1 & 0 \\
\hline 1907 & 70,6 & 81,5 & 152,1 & $+10,9$ & 31,2 & 14,0 \\
\hline 1908 & 75,6 & 77,7 & 153,3 & $+2,1$ & 0,8 & $-5,0$ \\
\hline 1909 & 73,5 & 93,0 & 166,5 & $+19,5$ & 8,6 & 19,7 \\
\hline 1910 & 84,7 & 98,4 & 183,1 & $+13,7$ & 9,9 & 5,8 \\
\hline 1911 & 115,4 & 116,9 & 232,3 & $+1,5$ & 26,9 & 18,8 \\
\hline 1912 & 106,1 & 84,2 & 190,3 & $-21,9$ & $\begin{array}{l}-18.0 \\
\end{array}$ & $-27,9$ \\
\hline
\end{tabular}

* Annual growth rate

Source: 1. For 1869-1908 Statistički godišnjak Kraljevine Srbije1907 i 1908, 1913, p.506.

2. For 1909-1912 Statistik aspoljne trgovine Kraljevine Srbije za 1912, Državna štamparija Kraljevine Srbije, 1911 i 1914. 
Table 2. Population of the Kingdom of Serbia 1884-1911

\begin{tabular}{|c|c|c|c|c|c|}
\hline Year & Total & Towns & Belgrade & Towns in $\%$ of total & Belgrade in $\%$ of total \\
\hline 1884 & 1901736 & 235887 & - & 12 & - \\
\hline 1885 & 1946354 & & & & \\
\hline 1886 & 1977224 & & & & \\
\hline 1887 & 2026958 & & & & \\
\hline 1888 & 2077427 & & & & \\
\hline 1889 & 2123362 & & & & \\
\hline 1890 & 2161961 & 286466 & 54249 & 13 & 3 \\
\hline 1891 & 2191908 & & & & \\
\hline 1892 & 2211606 & & & & \\
\hline 1893 & 2240270 & & & & \\
\hline 1894 & 2272992 & & & & \\
\hline 1895 & 2312484 & 319375 & 59115 & 14 & 3 \\
\hline 1896 & 2345837 & 321493 & 59237 & 14 & 3 \\
\hline 1897 & 2384205 & 323734 & 51259 & 14 & 2 \\
\hline 1898 & 2413694 & 324769 & 59223 & 13 & 2 \\
\hline 1899 & 2450392 & & & & \\
\hline 1900 & 2492882 & 351015 & 69769 & 14 & 3 \\
\hline 1901 & 2535956 & 353834 & 69990 & 14 & 3 \\
\hline 1902 & 2571517 & 355323 & 69904 & 14 & 3 \\
\hline 1903 & 2621576 & 356963 & 69823 & 14 & 3 \\
\hline 1904 & 2671505 & 358969 & 69725 & 13 & 3 \\
\hline 1905 & 2688025 & 404784 & 77816 & 15 & 3 \\
\hline 1906 & 2735147 & 348434 & 77504 & 13 & 3 \\
\hline 1907 & 2784036 & 350159 & 77280 & 13 & 3 \\
\hline 1908 & 2821015 & 350682 & 76965 & 12 & 3 \\
\hline 1909 & 2847861 & - & - & - & - \\
\hline 1910 & 2911701 & 384822 & 89876 & 13 & 3 \\
\hline 1911 & 2946783 & - & - & - & - \\
\hline
\end{tabular}

Source: 1 . Statistički godišnjak Kraljevine Srbije, various years.

2. Dva veka razvoja Srbije - Statistički pregled (Two Centuries of Serbian DevelopmentStatistical Review), (oktobar 2008): Republički zavod za statistiku, Beograd, p. 
Table 3. Population and Banks 1884-1911

\begin{tabular}{|c|c|c|c|}
\hline Year & Population & Number of Banks & Inhabitants per Bank \\
\hline 1884 & 1901736 & 7 & 271676 \\
\hline 1885 & 1946354 & - & - \\
\hline 1886 & 1977224 & - & - \\
\hline 1887 & 2026958 & - & - \\
\hline 1888 & 2077427 & 37 & 56146 \\
\hline 1889 & 2123362 & 40 & 53084 \\
\hline 1890 & 2161961 & 42 & 52188 \\
\hline 1891 & 2191908 & 45 & 48709 \\
\hline 1892 & 2211606 & 67 & 33009 \\
\hline 1893 & 2240270 & 61 & 36725 \\
\hline 1894 & 2272992 & 62 & 36661 \\
\hline 1895 & 2312484 & 66 & 35037 \\
\hline 1896 & 2345837 & 69 & 33997 \\
\hline 1897 & 2384205 & 69 & 34553 \\
\hline 1898 & 2413694 & 76 & 31791 \\
\hline 1899 & 2450392 & 76 & 32242 \\
\hline 1900 & 2492882 & 81 & 30776 \\
\hline 1901 & 2535956 & 92 & 27564 \\
\hline 1902 & 2571517 & 105 & 24538 \\
\hline 1903 & 2621576 & - & - \\
\hline 1904 & 2671505 & 111 & 24067 \\
\hline 1905 & 2688025 & 114 & 23585 \\
\hline 1906 & 2735147 & 118 & 23179 \\
\hline 1907 & 2784036 & 129 & 21581 \\
\hline 1908 & 2821015 & 146 & 19322 \\
\hline 1909 & 2847861 & 150 & 18985 \\
\hline 1910 & 2911701 & 163 & 17863 \\
\hline 1911 & 2946783 & 175 & 16838 \\
\hline
\end{tabular}

Source: Statistički godišnjak Kraljevine Srbije, various years. 


\section{Prof. dr Biljana Stojanović}

Geoekonomski fakultet, Univerzitet Džon Nezbit, Beograd

\section{NASTANAK I RAST SRPSKOG BANKARSTVA DO PRVOG SVETSKOF RATA Drugi deo:}

\section{Nacionalna država i nacionalno bankarstvo (1878-1914)}

Razvoj srpskog bankarstva tokom 19. veka je bio postepen proces koji je imao dve faze sa prekretnicom 1878. godine, kada je medunarodnim ugovorom Srbiji priznat status nezavisne države na Berlinskom kongresu. U prvoj fazi, do 1878. godine, stvarali su se neophodni politički, ekonomski i institucionalni preduslovi za pojavu bankarstva koji su doveli do stvaranja prvih organizovanih kredita i banaka. U drugoj fazi je odlučno sprovođenje ekonomskog i institucionalnog razvoja i modernizacije rezultiralo u velikom porastu banaka. Pored Privilegovane narodne banke Kraljevine Srbije (Narodna banka), kao emisione banke, postojale su državne banke i privatne banke koje su uglavnom bile u obliku akcionarskih društava. Od 1894. godine, poljoprivrednici su počeli da osnivaju seljačke zadruge koje su zadovoljavale kreditne potrebe seljaka po mnogo povoljnijim uslovima od banaka. Analiza ukazuje na zaključak da su banke u Kraljevini Srbiji u periodu 1878-1914. godina, više služile razvoju trgovine, izgradnji infrastrukture (železnica) $i$ industrije nego zadovoljavanju kreditnih potreba poljoprivrednika koji su bili glavni ekonomski akteri zemlje u kojoj su činili 85\% ukupnog stanovništva.

Ključne reči: kreditne institucije, banke, Narodna banka, tražnja za kreditom, kamate, uplaćeni kapital, zelenaštvo, strane banke. 